Review Article

\title{
From Diagnosis to Management; Mucocele of Stump Appendicitis, Extremely Rare Finding in an Uncommon Surgical Disease: Literature Review
}

\author{
Syed Muhammad Ali (iD), ${ }^{1}$ Mohannad Al-Tarakji $\left(\mathbb{D},{ }^{1}\right.$ Fakhar Shahid $(\mathbb{D}){ }^{2}$ \\ Amjad Salah Qabani $\left(\mathbb{0},{ }^{1}\right.$ Amjad Ali Shah $\left(\mathbb{0},{ }^{1}\right.$ Khalid Ahmed $\left(\mathbb{D},{ }^{1}\right.$ \\ Muhammad Burhan Khan $\mathbb{1},{ }^{1}$ and Inamullah ${ }^{1}$ \\ ${ }^{1}$ Department of Acute Care Surgery, Hamad Medical Corporation, Doha, Qatar \\ ${ }^{2}$ Department of Surgery, Hamad Medical Corporation, Doha, Qatar \\ Correspondence should be addressed to Syed Muhammad Ali; alismc2051@gmail.com
}

Received 14 August 2020; Revised 8 January 2021; Accepted 29 January 2021; Published 11 February 2021

Academic Editor: C. H. Yip

Copyright (C) 2021 Syed Muhammad Ali et al. This is an open access article distributed under the Creative Commons Attribution License, which permits unrestricted use, distribution, and reproduction in any medium, provided the original work is properly cited.

\begin{abstract}
Mucocele of the appendix is the accumulation of mucoid material in the appendiceal lumen. Although the terminology is imprecise, as it does not differentiate between the benign and malignant nature of the condition, preoperative recognition is imperative as spillage of the mucus during surgical handling can result in grave complications like pseudomyxoma peritonei. Mucocele developing in a stump of the appendix, i.e., a remnant of appendiceal tissue after surgical removal of an inflamed organ, is an extremely uncommon phenomenon, as not many cases are reported in the literature. In this review, all cases reported in English literature are discussed.
\end{abstract}

\section{Introduction}

Mucocele developing into an appendiceal stump is an uncommon lesion, as only a few cases are reported. Recognition of this condition can be challenging because of its rarity and nonspecific symptoms [1-4]. The surgical procedure should be carried out with utmost caution, whether it is diagnosed preoperatively or encountered incidentally during the surgery, as the manipulation can result in mucus release into the peritoneum leading to drastic complications [1-5]. Due to the rarity of this condition, a comprehensive review of all reported cases is described $[1,6,7]$.

\section{Methods}

A thorough search of English literature was carried out with terms including stump, stump appendicitis, mucocele, and mucocele in stump in PubMed, Embase, and Google scholar and the references of all articles. More than 200 cases are reported in English literature for stump appendicitis after an initial appendectomy in the past and then developing into one of the complications like a mucocele in the stump. The data of all the articles were collected including history, examination, radiological findings, especially CT (computed tomography), operative details, and histopathology in a tabulated form.

\section{Results}

Ten cases of mucocele in the stump of the appendix were found in English literature. Tables 1 and 2 show the age, clinical features, time after index/initial appendectomy, radiological investigations with findings, operative procedure, and follow-up of all the cases. Age of the patients ranged from 27 to 79 years. Time of presentation of the mucocele in stump varied as early as four years to the latest by 40 years after the first surgery. Most of the patients presented with right lower quadrant abdominal pain or 
TABLE 1: Review of literature of appendiceal mucocele in stump appendix.

\begin{tabular}{|c|c|c|c|c|c|c|c|}
\hline No. & Author & Age & Gender & Presentation & Interval between appendectomy & Open vs. lap & Time of diagnosis \\
\hline 1 & $\begin{array}{l}\text { Rasch and } \\
\text { Strange [8] }\end{array}$ & 54 & Male & $\begin{array}{l}\text { Right lower abdominal } \\
\text { pain }\end{array}$ & 4 years & Open & Post-op \\
\hline 2 & $\begin{array}{l}\text { Ozgür } \\
\text { et al. [6] }\end{array}$ & 75 & & $\begin{array}{c}\text { Abdominal pain, } \\
\text { nausea and vomiting, } \\
\text { and mass on } \\
\text { examination }\end{array}$ & 10 years & Not mentioned & Pre-op \\
\hline 3 & $\begin{array}{c}\text { Cama } \\
\text { Jitoko K } \\
{[21]} \\
\end{array}$ & 27 & Female & $\begin{array}{c}\text { Chronic abdominal } \\
\text { pain in RIF for } 12 \\
\text { months }\end{array}$ & 18 years & Open & Post-op \\
\hline 4 & $\begin{array}{l}\text { El Ajmi } \\
\text { et al. [10] }\end{array}$ & 54 & Female & $\begin{array}{c}\text { 3-week history of pain } \\
\text { in the right lower } \\
\text { quadrant of the } \\
\text { abdomen }\end{array}$ & 20 years & Not mentioned & Post-op \\
\hline 5 & $\begin{array}{c}\text { Kim et al. } \\
{[1]}\end{array}$ & 78 & Male & $\begin{array}{l}\text { Palpable mass in the } \\
\text { right upper thigh and } \\
\text { swelling of the right } \\
\text { lower extremity for } 2 \\
\text { months }\end{array}$ & 40 years ago & Open & Post-op \\
\hline 6 & $\begin{array}{c}\text { Sameera } \\
\text { and Sohil } \\
{[11]}\end{array}$ & 51 & Male & $\begin{array}{l}\text { Complaints of flank } \\
\text { pain and hematuria }\end{array}$ & Not mentioned & Not mentioned & Pre-op \\
\hline 7 & $\begin{array}{l}\text { Korkolis } \\
\text { et al. [3] }\end{array}$ & 49 & Female & $\begin{array}{l}\text { 6-month history of } \\
\text { vague right lower } \\
\text { quadrant pain } \\
\text { radiating through to } \\
\text { the back }\end{array}$ & 25 years previously & Not mentioned & Post-op \\
\hline 8 & $\begin{array}{l}\text { Lien et al. } \\
{[2]}\end{array}$ & 66 & Male & $\begin{array}{l}\text { Gradual onset of right } \\
\text { lower quadrant (RLQ) } \\
\text { pain }\end{array}$ & 30 years & $\begin{array}{l}\text { Not mentioned but } \\
\text { presumably open }\end{array}$ & Post-op \\
\hline 9 & $\begin{array}{l}\text { Lien et al. } \\
{[2]}\end{array}$ & $\begin{array}{c}45 \\
\text { years }\end{array}$ & Female & $\begin{array}{c}\text { 3-day history of RLQ } \\
\text { pain associated with } \\
\text { low-grade fever } \\
\left(37.8^{\circ} \mathrm{C}\right) \text { and diarrhea }\end{array}$ & 10 years previously & $\begin{array}{l}\text { Not mentioned } \\
\text { (but they } \\
\text { mentioned surgical } \\
\text { scar, it looks open) }\end{array}$ & No pre-op diagnosis \\
\hline 10 & $\begin{array}{l}\text { Yeong } \\
\text { et al. [12] }\end{array}$ & $\begin{array}{c}54 \\
\text { years }\end{array}$ & Male & $\begin{array}{l}\text { Painless abdominal } \\
\text { mass which he first } \\
\text { noticed } 5 \text { years ago, } \\
\text { gradually increasing in } \\
\text { size }\end{array}$ & $\begin{array}{l}\text { Appendicectomy for an } \\
\text { appendiceal abscess } 25 \text { years } \\
\text { previously. The perforated } \\
\text { appendix was in the prececal } \\
\text { position, adherent to the terminal } \\
\text { ileum and covered by omentum }\end{array}$ & $\begin{array}{l}\text { Not mentioned but } \\
\text { it looks open }\end{array}$ & $\begin{array}{l}\text { Pre-op diagnosis of } \\
\text { mesenteric or } \\
\text { reduplication cyst } \\
\text { was suggested }\end{array}$ \\
\hline
\end{tabular}

mass. All the patients were diagnosed preoperatively by imaging, and CT abdomen was the investigation of choice except one author who mentioned typical finding in ultrasound abdomen, accurately diagnosing the condition. Right hemicolectomy was the standard surgical procedure carried out in all but two patients in whom stump appendectomy with excision of mucocele was accomplished. The malignancy was ruled out partly by the size in one and frozen section in another patient in whom right hemicolectomy was not performed. One case of papillary cystadenocarcinoma was reported with peritoneal deposits, and another was mucinous cystadenocarcinoma. Follow-up was reported in 4 patients only, where the patients remained well between 1.5 and 4 years.

\section{Discussion}

Although first mentioned by Karl Freiherr von Rokitansky in 1842, Fere in 1877 coined the term mucocele and described it as appendicular dilatation secondary to accumulation of mucinous material in the lumen [8-14]. Factors, mentioned earlier by Rasch, leading to mucocele can be stenosis of appendiceal lumen with unabated mucus production and an absence of infection $[8,9,13]$. The remnant of appendix remaining attached to cecum after surgical removal of inflamed organ is called "stump". It is usually less than $0.5 \mathrm{~cm}$ and does not lead to any further problem; however, in rare cases, it may develop inflammation when it is known as stump appendicitis. The 
TABLE 2: Investigations, surgical procedure, histopathology, and outcomes.

\begin{tabular}{|c|c|c|c|c|}
\hline Author & Investigations & Surgical procedure & Histopathology & Outcome \\
\hline $\begin{array}{l}\text { Rasch and } \\
\text { Strange }[8]\end{array}$ & $\begin{array}{l}\text { Barium enema: smooth } \\
\text { deformity of the inferomedial } \\
\text { border of the cecum with } \\
\text { pressure on the terminal ileum }\end{array}$ & $\begin{array}{l}\text { Exploratory laparotomy and } \\
\text { right hemicolectomy }\end{array}$ & $\begin{array}{c}\text { Cecal wall thickened with } \\
\text { connective and muscular tissue } \\
\text { Large amounts of mucous material, } \\
\text { occurring in lakes of considerable } \\
\text { size } \\
\text { Fibrosis and occasional groups of } \\
\text { normal mucus secreting cells }\end{array}$ & $\begin{array}{c}\text { Discharged after } 2 \\
\text { weeks }\end{array}$ \\
\hline $\begin{array}{l}\text { Ozgür } \\
\text { et al. [6] }\end{array}$ & $\begin{array}{l}\text { CT abdomen (hypoattenuating, } \\
10 * 9 * 8 \mathrm{~cm} \text { mass lying in the } \\
\text { retrocecal region) } \\
\text { US abdomen } 10 \times 9 \times 8 \mathrm{~cm} \text { mass } \\
\text { with multiple echogenic layers in } \\
\text { a wavy pattern filling the entire } \\
\text { lesion, with thin but smooth wall }\end{array}$ & $\begin{array}{c}\text { Exploratory laparotomy } \\
(9 \times 7 \times 3 \mathrm{~cm} \text { mass and a fixed } \\
\text { tumor adherent to the } \\
\text { abdominal wall, posterior to the } \\
\text { cecum } \\
\text { Right hemicolectomy }\end{array}$ & $\begin{array}{c}\text { Firm mass of } 9 \times 7 \times 1.5 \mathrm{~cm} \text { near the } \\
\text { ileocecal region } \\
\text { Normal colonic mucosa papillary } \\
\text { projections of the mucinous } \\
\text { adenocarcinoma lining the } \\
\text { appendiceal mucosa }\end{array}$ & No follow-up \\
\hline $\begin{array}{l}\text { Cama } \\
\text { Jitoko K } \\
{[21]}\end{array}$ & US scan: normal & $\begin{array}{l}\text { Diagnostic laparoscopy cystic } \\
\text { lesion arising from the base of } \\
\text { the stump of appendix } \\
3 \times 2 \mathrm{~cm} \text {, excised } \\
\text { laparoscopically }\end{array}$ & $\begin{array}{l}\text { Periappendicitis with chronic } \\
\text { inflammation and fibrosis }\end{array}$ & No follow-up \\
\hline $\begin{array}{l}\text { El Ajmi M, } \\
2009[10]\end{array}$ & $\begin{array}{l}\text { US scan: hypoechogenic mass } \\
\qquad 90 \times 65 \times 55 \mathrm{~mm} \\
\text { CT: retroperitoneal cystic } \\
\text { structure measuring } 13 \times 58 \mathrm{~cm} \text {, } \\
\text { without mural calcification }\end{array}$ & $\begin{array}{l}\text { Laparotomy } \\
\text { Retroperitoneal cystic mass } \\
\text { right ileocecal resection with } \\
\text { sufficient margins }\end{array}$ & $\begin{array}{l}\text { Mucinous cystadenoma of the } \\
\text { appendiceal stump } \\
\text { Five lymph nodes examined were } \\
\text { free from the tumor } \\
\text { Margins of resection and cytology } \\
\text { were negative }\end{array}$ & $\begin{array}{l}\text { Discharge on the } \\
4^{\text {th }} \text { postoperative } \\
\text { day }\end{array}$ \\
\hline
\end{tabular}

Doppler US : a well-defined

lobulated mass $(10 * 6 * 30 \mathrm{~cm})$ in the right lower abdomen extending into the right upper thigh

Kim et al. CT: elongated, cystic mass in the [1] extraperitoneal space of the right lower quadrant extending into the right thigh along the right femoral canal, indenting medial aspect and possibly originating from the cecum (i.e., the expected location of the appendix)

Ultrasound: $6 \mathrm{~cm}$ cystic lesion around the inferior pole of the right kidney $\mathrm{CT}$

Sameera No lesion in kidney but a tubular and Sohil cystic structure in the right flank [11] with inferior tip at the same site of previously inflamed appendix stump base, mucocele of stump

Korkolis et al. [3]
CT : elliptical, $7 \times 5 \mathrm{~cm}$ cystic mass, lying at the inferior aspect of the cecum; the lesion had smooth walls, scattered mural calcifications, and no surrounding inflammation
Two separate incisions, the cecum, terminal ileum, and a portion of the mass above the right femoral canal were removed with an ileocolostomy Mass below the right femoral canal was removed separately

\section{Mucinous cystadenoma}

No evidence of recurrence 3 years after surgery Exploratory laparotomy and
mucocele resected
The patient was discharged well
Exploratory laparotomy, wellencapsulated and calcified tumor, $8 \times 5.5 \times 4 \mathrm{~cm}$ in size, at the base of originating from the one $\mathrm{cm}$, unburied, appendiceal stump

Limited cecal resection with the mass
Histopathology revealed crowded, villotubular structures, with mild to moderate epithelial atypia together with acellular mucin pooling $(75 \mathrm{ml}$ mucin)

No evidence of malignancy

Appendiceal stump mucocele associated with a benign mucinous cystadenoma
Discharged home on the fifth postoperative day 18 months after surgery, free of symptoms

No recurrence 
TABLE 2: Continued.

\begin{tabular}{|c|c|c|c|c|}
\hline Author & Investigations & Surgical procedure & Histopathology & Outcome \\
\hline $\begin{array}{l}\text { Lien et al. } \\
\text { [2] }\end{array}$ & $\begin{array}{l}\text { US: dumbbell-shaped, } \\
\text { heterogeneous cystic mass with } \\
\text { internal echoes, } 5 \times 5 \mathrm{~cm} \text { in } \\
\text { diameter in the right lower } \\
\text { abdomen } \\
\text { CT demonstrated a cystic mass at } \\
\text { the inferior aspect of the cecum }\end{array}$ & $\begin{array}{c}\text { Right hemicolectomy; an } 8.3^{*} \\
6^{*} 3.5 \mathrm{~cm} \text { dumbbell-shaped } \\
\text { tumor containing yellowish } \\
\text { mucus originating from the } \\
1 \mathrm{~cm} \text { unburied appendiceal } \\
\text { stump }\end{array}$ & Mucinous cystadenoma & $\begin{array}{c}\text { Uneventful } \\
\text { postoperative } \\
\text { course } \\
\text { No recurrence at } 2 \\
\text { years }\end{array}$ \\
\hline $\begin{array}{l}\text { Lien et al. } \\
{[2]}\end{array}$ & $\begin{array}{l}\text { US showed an elongated cystic } \\
\text { mass with internal echoes } \\
\text { CT : well-defined cystic lesion } \\
\text { without surrounding } \\
\text { inflammation adjacent to the } \\
\text { cecum and displacing the } \\
\text { terminal ileum }\end{array}$ & $\begin{array}{c}\text { The patient refused surgical } \\
\text { intervention }\end{array}$ & None & $\begin{array}{l}\text { She has remained } \\
\text { well during the } \\
\text { subsequent } 4 \text { years }\end{array}$ \\
\hline $\begin{array}{l}\text { Yeong, } \\
{[16]}\end{array}$ & $\begin{array}{l}\text { CT : intraperitoneal cystic mass } \\
\text { in the right upper quadrant with } \\
\text { peripheral calcification }\end{array}$ & $\begin{array}{c}\text { Laparotomy } \\
\text { Mass adherent to terminal } \\
\text { ileum, cecum, and ascending } \\
\text { colon } \\
\text { The right iliac fossa contained } \\
\text { scattered grey, mucoid nodules } \\
\text { up to } 0.4 \mathrm{~cm} \text { in diameter } \\
\text { Cyst not separated from the } \\
\text { colon } \\
\text { Right hemicolectomy }\end{array}$ & $\begin{array}{l}\text { Mucocele due to a papillary } \\
\text { cystadenocarcinoma arising in an } \\
\text { appendiceal stump and associated } \\
\text { with peritoneal metastases }\end{array}$ & Not mentioned \\
\hline
\end{tabular}

first case of stump appendicitis was described by De Ruyter in 1945 (only around 200 cases have thus been reported in the English literature) [15-17].

The incidence of appendiceal mucoceles has variously been reported as $0.07-0.3 \%$ of all the appendectomy specimen $[11,12,18]$ and that of appendiceal stump is further rare, as we collected and reviewed 10 cases in the literature [8].

Following mechanisms are proposed for the development of appendicular mucoceles and possibly stump mucoceles as well (World Health Organisation classification) $[3,12,19,20]$.

(1) Obstruction of the proximal end secondary to inflammation and confinement of mucus. Normal or ulcerated appendiceal mucosa lines the mucocele, and these are known as retention cysts $[12,21]$, simple mucocele $[12,22]$, or ectasia of the appendix $[12,20]$.

(2) Mucosal lining may change as seen in hyperplastic polyp of the colon [20].

(3) Sometimes, lining of the mucocele is composed of atypical (papillary epithelium) reminiscent of adenomatous polyp of the large bowel [12].

(4) Presence of cystadenocarcinoma where the epithelium is the same as in cystadenoma but demonstrates the features of stromal invasion by the neoplastic cells, and there may be cells in peritoneal deposits as mentioned by the Higa and others [9, 20, 23, 24].

(5) Mucocele may result when an invasive adenocarcinoma (mucus secreting) affects the appendix $[12,19]$.

Hung mentioned obstruction of the appendiceal lumen by endometriosis and further exceptionally by inspissated mucus in cases of cystic fibrosis [25, 26]. These are the mechanisms whereby mucoceles may develop after appendectomy possibly by obstruction of the distal end of the stump, and one protective mechanism suggested is to leave a smaller stump usually $<5 \mathrm{~mm}$ from the base [25].

Clinical manifestations are nonspecific; therefore, diagnosis is not usually straightforward. History of past appendectomy also poses difficulty and complexity in diagnosis. There is a reported delay of 4-30 years in diagnosis after the index appendectomy [7]. Patients often present with right lower quadrant abdominal pain, a slowly enlarging mass in the abdomen [12, 21, 27], unexplained and unintentional weight loss, nausea, vomiting, or bleeding per rectum. A quarter of the patients may have clinical features indistinguishable from acute appendicitis [3, 6, 27]. There are higher chances of perforations in cases of stump appendicitis, as mentioned by Liang, Thomas, and RocheNagle [17, 21, 28, 29]. In some cases, there is a history of slowly growing abdominal mass $[12,21,27]$ that can be mistaken as duplication cysts, mesenteric cysts, abscess/ hematoma, urachal cyst, or lymphangioma [1, 13, 30-32]. Occasionally, the mucoceles may be an incidental finding on exploration of the abdomen, radiological investigation, or endoscopic procedures carried out for other reasons [10, 21]. Connor mentioned if the mucoceles are symptomatic, then there is a likelihood of harboring malignancy [33]. The size has been shown to be related to malignant potential, and lesions $<2 \mathrm{cms}$ are mostly benign and $>6 \mathrm{cms}$ are usually cystadenoma or cystadenocarcinoma. [34].

There has been an association of the appendiceal mucoceles with increased incidence of colorectal neoplasms and to a lesser extent ovarian, endometrial, prostate, and other gastrointestinal 
malignancies, as reported by Fujiwara et al. [35]. Therefore, surveillance colonoscopy is recommended in patients diagnosed with and histopathology proven cystadenoma [3]. As mentioned, the most common presentation is vague lower abdominal pain and mass in the lower abdomen with a history of appendectomy in the previous years. One rare presentation of stump mucocele was right-sided inguinal hernia secondary to pseudomyxoma peritonei [20] and a mass extending from abdomen to thigh through the right femoral canal [1], possibly by extravasation of the mucus from appendicular mucocele into the retroperitoneum. A few patients may have a history of weight loss and altered bowel habits [6]. Certain complications may arise like intussusception, bleeding, perforation leading to peritonitis, rupture, and pseudomyxoma peritonei, which, although, are rare but can be fatal [6]. In cases of pseudomyxoma secondary to mucocele (of appendix or stump), the abdomen is filled with mucus and there might be presence or absence of epithelial cells, and according to Aho, the cellular component carries a poor prognosis [12, 21]. Yeong et al. reported a case of stump mucocele harboring papillary cystadenocarcinoma, as described by the Ozgur in their patient as well $[6,12]$.

Preoperative localization along with characterization is important in decision-making and alarms the operating surgeon to be extremely careful in not spilling the contents in the peritoneal cavity. Spontaneous rupture has been reported leading to pseudomyxoma and signifies high chances of malignancy $[4,6]$. Notable diagnostic modalities include ultrasound, barium enema, colonoscopy, and CT abdomen $[2,3,6,11,12]$. Typical ultrasound findings include multiple echogenic layers in an anechoic or varied echotextures cystic mass known as "onion-skin sign" as described by Caspi et al. [36]. CT abdomen, especially the multidetector (MDCT), is the radiological investigation of choice for diagnosis and further evaluation. A mass in the right lower quadrant of abdomen with mixed CT attenuation (due to mucin contents) located in close proximity and showing continuity to cecum along with calcification of the wall provides sufficient evidence to diagnose stump mucocele $[2,3,37,38]$. Mural calcification is seen in half of the lesions; therefore, the distinction between mucocele and cecum is challenging in larger masses, but coronal sections are especially helpful in delineating the origin $[4,33]$. Barium enema was used frequently in the past for diagnosing colonic pathologies, and in one earliest case, it showed smooth deformity or indentation of the inferomedial cecal wall, implying a pressure effect on the terminal ileum [8]. Colonoscopy can likewise demonstrate a bulge produced by the external compression of the cecum [11].

In the recent era, MDT (multidisciplinary teams) meetings are suggested to improve the management and outcome of all, particularly neoplastic diseases, so every case diagnosed preoperatively should be discussed, and appropriate management strategy is individualized. A surgical procedure in the form of limited ileocecal resection or right hemicolectomy is suggested as an optimum treatment for the mucocele of the stump appendix $[1,3,6,8,10,11,25]$. Open surgical exploration was performed in almost all cases, but laparoscopic resection has been suggested by Cama in which a $3 * 2 \mathrm{cms}$ stump mucocele was resected successfully. Almost all authors have suggested and stressed on the extreme care for not damaging the specimen during handling as the sequelae can be disastrous. Some have argued as the right hemicolectomy does not offer a survival advantage, so appendectomy or cecectomy with negative margins is a preferable method of treatment [34]. El Ajmi et al. preferred to perform right hemicolectomy and lymph node dissection, as there was suspicion of malignancy [10]. Histopathology of all the cases reviewed was benign except for two. Since there are only a few cases reported, a guideline could not be formulated though right hemicolectomy is a plausible choice in all but very small, localized lesions. The follow-up for some of the benign cases have been reported, but none has been mentioned for the two malignant patients who were operated by radical resections, and it is recommended in all patients as they may develop any other type of gastrointestinal malignancies.

\section{Conclusion}

Mucoceles in appendix are rarely encountered and in stump of appendix is further infrequent. A few cases are reported, and the most common presentation is with vague lower abdominal pain or slowly growing mass. US and CT scans are diagnostic in all cases, and surgical removal in the form of right hemicolectomy is the treatment of choice although stump appendectomy can be considered in smaller lesions. Resection should be carried out with utmost precaution to remove the mass intact as rupture may lead to catastrophic consequences. Multidisciplinary teams can play a vital role in managing the individual patients, and postoperative surveillance is needed as there are chances of other gastrointestinal neoplastic lesions in the future.

\section{Data Availability}

The data used to support the findings of this study are included within the article.

\section{Conflicts of Interest}

The authors declare that they have no conflicts of interest.

\section{References}

[1] M. K. Kim, H. Y. Lee, I. S. Song et al., "A case of a giant mucocele of the appendiceal stump presented with a palpable mass in the right thigh: pre-operative diagnosis based on characteristic multidetector CT findings," The British Journal of Radiology, vol. 83, pp. 220-223, 2010.

[2] W.-C. Lien, K.-L. Liu, M.-Y. Kuo et al., "Mucocele of appendiceal stump," Surgery, vol. 136, no. 1, pp. 93-94, 2004.

[3] D. P. Korkolis, K. Apostolaki, G. D. Platanoitis, J. Tzorbatzoglou, I. G. Karaitinanos, and P. P. Vassilopoulos, "Mucocele of the appendiceal stump due to benign mucinous cystadenoma," Anticancer Research, vol. 26, pp. 635-638, 2006.

[4] L. Stocchi, B. G. Wolff, D. R. Larson, and J. R. Harrington, "Surgical treatment of appendiceal mucocele," Archives of Surgery, vol. 138, no. 6, pp. 585-590, 2003.

[5] S. Gonza'lez Moreno, B. M. Shmookler, and P. H. Sugarbaker, "Appendiceal mucocele. Contraindication to laparoscopic appendectomy," Surgical Endoscopy, vol. 12, pp. 1177-1179, 1998. 
[6] A. Ozgür, G. Çabuk, M. Nass Duce, M. Cereb Tombak, and K. Esen, "Appendiceal mucocele due to mucinous cystadenocarcinoma arising from the appendiceal stump: preoperative diagnosis based on the "onion skin sign"” Japanese Journal of Radiology, vol. 30, no. 8, pp. 684-687, 2012.

[7] M. A. Johnson, D. Jyotibasu, P. Ravichandran, S. Jeswanth, D. G. Kannan, and R. Surendran, "Retention mucocele of distal viable remnant tip of appendix: an unusually rare late surgical complication following incomplete appendectomy," World Journal of Gastroenterology, vol. 12, no. 3, pp. 489-492, 2006.

[8] G. C. Rasch and D. C. Strange, "Mucocele of inverted appendiceal stump following appendectomy," Surgery, vol. 35, pp. 629-632, 1954.

[9] G. V. Aranha and C. V. Reyes, "Primary epithelial tumors of the appendix and a reappraisal of the appendiceal "mucocele"” Diseases of the Colon \& Rectum, vol. 22, no. 7, pp. 472-476, 1979.

[10] M. El Ajmi, W. Rebai, and Z. Ben Safta, "Mucocele of appendiceal stump-an atypical presentation and a diagnostic dilemma," Acta Chirurgica Belgica, vol. 109, no. 3, pp. 414-415, 2009.

[11] G. Sameera and P. Sohil, "Renal colic: a red herring for mucocele of the appendiceal stump," Case Reports in Emergency Medicine, vol. 2018, Article ID 2502183, 3 pages, 2018.

[12] M. L. Yeong, S. P. Clark, and R. S. Stubbs, "Papillary cystadenocarcinoma of the appendiceal stump with mucocele and peritoneal metastases," Pathology, vol. 21, no. 2, pp. 131-133, 1989.

[13] D. M. Yang, D. H. Jung, H. Kim et al., "Retroperitoneal cystic masses: CT, clinical, and pathologic findings and literature review," Radiographics, vol. 24, no. 5, pp. 1353-1365, 2004.

[14] C. Jiménez Mazure, C. P. Ramírez Plaza, M. Valle Carbajo, and J. Santoyo Santoyo, "Mucocele apendicular gigante. Implicaciones diagnósticas y terapéuticas," Revista Espanola de Enfermedades Digestivas, vol. 101, pp. 439-451, 2009.

[15] M. Al-Tarakji, S. M. Ali, M. Khalaf, S. Fakhar, and S. I. M. Sara, "Adenocarcinoma of stump appendicitis: an extremely rare pathology-a literature review," Cureus, vol. 12, no. 7, Article ID e9482, 2020.

[16] G. de Ruyter, "About carcinoma development. (Article in German)," Arch Klin Chir (Berl), vol. 69, p. 281, 1903.

[17] M. K. Liang, H. G. Lo, and J. L. Marks, "Stump appendicitis: a comprehensive review of literature," The American Surgeon, vol. 72, no. 2, pp. 162-166, 2006.

[18] S. Dhage-Ivatury and P. H. Sugarbaker, "Update on the surgical approach to mucocele of the appendix," Journal of the American College of Surgeons, vol. 202, no. 4, pp. 680-684, 2006.

[19] M. Wolff and N. Ahmed, "Epithelial neoplasms of the vermiform appendix (exclusive of carcinoid).II. Cystadenomas, papillary adenomas, and adenomatous polyps of the appendix," Cancer, vol. 37, no. 5, pp. 2511-2522, 1976.

[20] E. Higa, J. Rosai, C. A. Pizzimbono, and L. Wise, "Mucosal hyperplasia, mucinous cystadenoma, and mucinous cystadenocarcinoma of the appendix. A re-evaluation of appendiceal "mucocele"” Cancer, vol. 32, no. 6, pp. 1525-1541, 1973.

[21] A. J. Aho, R. Heinonen, and P. Laurén, "Benign and malignant mucocele of the appendix. Histological types and prognosis," Acta Chirurgica Scandinavica, vol. 139, no. 4, pp. 392-400, 1973.

[22] M. Steinberg and I. Cohn, "Primary adenocarcinoma of the appendix,” Surgery, vol. 61, no. 4, pp. 644-660, 1967.
[23] G. F. Gray and P. A. Wackym, "Surgical pathology of the vermiform appendix," Pathology Annual Part, vol. 2, pp. 111-144, 1986.

[24] A. Uihlein and J. R. McDonald, "Primary carcinoma of the appendix resembling carcinoma of the colon," Surgery, gynecology \& obstetrics, vol. 76, pp. 711-714, 1943.

[25] J. K. Cama, "Recurrent abdominal pain post appendectomy-a rare case. Case report and short communication," Fiji School of Medicine, vol. 16, no. 2, pp. 78-81, 2010.

[26] L. Hung, W. Yuen, L. Florence, and F. Lee, "Laparoscopic resection of appendiceal mucocele. Surgical laparoscopy," Endoscopy \& Percutaneous Techniques, vol. 12, no. 5, pp. 3677-4370, 2002.

[27] S. Landen, C. Bertrand, G. J. Madden et al., "Appendiceal mucoceles and pseudo-myxoma peritonei," Surgery, gynecology \& obstetrics, vol. 17, pp. 401-404, 1992.

[28] S. E. Thomas, D. A. Denning, and M. H. Cummings, "Delayed pathology of the appendiceal stump: a case report of stump appendicitis," The American Journal of Surgery, vol. 60, no. 11, pp. 842-844, 1994.

[29] G. Roche-Nagle, C. Gallagher, C. Kilgallen, and M. Caldwell, "Stump appendicitis: a rare but important entity," The Surgeon, vol. 3, no. 1, pp. 53-54, 2005.

[30] T. Persaud, N. Swan, and W. C. Torreggiani, "Giant mucinous cystadenoma of the appendix," Radiographics, vol. 27, no. 2, pp. 553-557, 2007.

[31] D. A. Pe'rez Fentes, M. Cortegoso Gonza'lez, A. Puñ al Pereira, A. Cimadevila Garci'a, S. Nova's Castro, and M. Blanco Parra, "Appendiceal mucocele misdiagnosed with infected urachal cyst: a differential diagnosis to keep in mind," Actas Urológicas Españolas, vol. 33, pp. 205-208, 2009.

[32] T. E. F. Jongsma and J. B. C. M. Puylaert, "Infection of a malignant appendiceal mucocele masquerading as an appendiceal abscess: role of preoperative sonography and CT," Journal of Clinical Ultrasound, vol. 37, no. 4, pp. 236-238, 2009.

[33] S. J. Connor, G. B. Hanna, and F. A. Frizelle, "Appendiceal tumors," Diseases of the Colon \& Rectum, vol. 41, no. 1, pp. 75-80, 1998.

[34] S. González-Moreno and P. H. Sugarbaker, "Right hemicolectomy does not confer a survival advantage in patients with mucinous carcinoma of the appendix and peritoneal seeding," British Journal of Surgery, vol. 91, no. 3, pp. 304-311, 2004.

[35] T. Fujiwara, A. Hizuta, T. Matsuno, M. Hamada, N. Tanaka, and K. Orita, "Appendiceal mucocele with concomitant colonic cancer," Diseases of the Colon \& Rectum, vol. 39, no. 2, pp. 232-236, 1996.

[36] B. Caspi, E. Cassif, R. Auslender, A. Herman, Z. Hagay, and Z. Appelman, "The onion skin sign," Journal of Ultrasound in Medicine, vol. 23, no. 1, pp. 117-121, 2004.

[37] G. L Bennet, T. P Tanpitukpongse, M. Macari, K. C Cho, and C. S Babb, "CT diagnosis of mucocele of the appendix in patients with acute appendicitis," American Journal of Roentgenology, vol. 192, 2009.

[38] R. Zissin, G. Gayer, E. Kots, S. Apter, M. Peri, and M. ShapiroFeinberg, "Imaging of mucocoele of the appendix with emphasis on the CT findings: A report of 10 cases," Clinical Radiology, vol. 54, no. 12, pp. 826-832, 1999. 